\section{Light and Temperature Govern Germination and Storage of Caladium Seed}

\author{
William J. Carpenter ${ }^{1}$ \\ Department of Ornamental Horticulture, IFAS, University of Florida, \\ Gainesville, FL 32611
}

Additional index words. Caladium hortulanum, germination recommendations, seed storage temperature, humidity

Abstract. Caladium hortulanum Birdsey Cv. Candidum seed failed to germinate without light; maximum germination required daily, incandescent light of $\geq 4$ hours. Lengthening daily lighting periods progressively reduced the days to $50 \%$ relative germination $\left(T_{50}\right)$ from 20 to 8 , and days between $10 \%$ and $90 \%$ relative germination $\left(T_{90}-T_{10}\right)$ from 16 to $5 . T_{50}$ and $T_{90}-T_{10}$ were shortest $(\approx 8$ days $)$ at 25 and $30 C$, while total or absolute germination percentage $(G)$ was highest at $\approx 90 \%$. G was $94 \%$ for seeds harvested immediately, but $75 \%$ or $38 \%$ for seeds that remained in fruits for 3 or 12 weeks after fruit abscission from the spadix. Total absolute germination was reduced from $95 \%$ to $87 \%$ when seed moisture contents declined to $<14 \%$. Seed storage for 7 days at from 10 to $-80 \mathrm{C}$ - caused no reduction in G. Seeds were stored 6 months at $15 \mathrm{C}$ and $22 \%, 33 \%$, or $52 \% \mathrm{RH}$ without change in $\mathrm{G}$, but storage at 5 or $25 \mathrm{C}$ and $11 \%, 75 \%$, or $95 \%$ RH significantly reduced germination.

Caladiums are produced commercially for multicolored foliage and marketed in the spring as pot, bedding, or landscape plants. Propagation is by division of tubers, although meristem-tip culture procedures are increasingly being used by commercial propagators (Harbaugh, 1983; Lecoufle, 1983; Post, 1949). Seed propagation is not used commercially because plants do not breed true. Seed inbred lines are being developed to reduce plant variability (Wilson and Nell, 1984). Caladium seed viability rapidly declines after drying and storage for 2 weeks or longer at 23C and 58\% RH (Hartman et al., 1972). Seeds will germinate in 8 to 14 days immediately after removal from fruits, but germination is irregular (Job et al., 1982). A major gap exists in the literature on the influence of germination temperature, relative humidity, and seed storage conditions. Research objectives were to determine light and temperature effects on caladium seed germination and the influence of temperature and relative humidity levels on seed storage duration.

Light and temperature studies. Caladium seeds from controlled crosses among selected inbred lines of 'Candidum' were ob-

Received for publication 14 Feb. 1989. Florida Agricultural Experiment Station Journal Series no. 9713. I acknowledge the seed source and technical assistance of Gary J. Wilfret, Gulf Coast REC, Bradenton, Fla. The cost of publishing this paper was defrayed in part by the payment of page charges. Under postal regulations, this paper therefore must be hereby marked advertisement solely to indicate this fact.

${ }_{1}$ Professor of Ornamental Horticulture. tained from a breeding program. Fruits ripened 6 weeks after pollination and abscissed from the spadix at maturity when ovaries were cream-color. Seeds in all studies were cleaned by removing the fruit pulp; they then were surface-dried and dusted with 3a,4,7,7a-tetrahydro-2-[(trichloromethyl)thio]-1H-isoindole-1,3(2H)-dione (captan) before germi-
Table 1. Influences of temperature on the germination of caladium seeds receiving continuous light.

\begin{tabular}{cccc}
\hline \hline \multirow{2}{*}{$\begin{array}{c}\text { Temperature } \\
\left({ }^{\circ} \mathrm{C}\right)\end{array}$} & \multicolumn{3}{c}{ Germination } \\
\cline { 2 - 4 } & $\mathrm{G}^{\mathbf{z}}$ & $\mathrm{T}_{\mathbf{5 0}}{ }^{\mathrm{y}}$ & $\mathrm{T}_{\mathbf{9 0}}-\mathrm{T}_{\mathbf{1 0}}{ }^{\mathrm{x}}$ \\
\hline 10 & 0 & $\ldots-$. & $\ldots$ \\
15 & 9 & 18 & 19 \\
20 & 37 & 15 & 14 \\
25 & 91 & 8 & 7 \\
30 & 88 & 9 & 9 \\
35 & 42 & 16 & 15 \\
40 & 0 & $\cdots$ & $\cdots$ \\
Significance & & & \\
Linear & $*$ & NS & NS \\
Quadratic & $* *$ & $* *$ & $* *$ \\
Cubic & $*$ & NS & NS \\
\hline
\end{tabular}

${ }^{2}$ Percent absolute final germination after 40 days. 'Days to $50 \%$ relative germination.

${ }_{\mathrm{N}}^{\mathrm{x}}$ ays from $10 \%$ to $90 \%$ relative germination. , * * * Nonsignificant or Significant at $\mathrm{P}=0.05$ or 0.01 , respectively; data are means of 400 seeds.

nation. In all experiments, there were four 100 -seed replicates for each treatment. In this study, seeds of each replicate were germinated in individual 9-cm petri dishes on a double layer of Whatman no. 1 filter paper moistened with $5 \mathrm{ml}$ of distilled water. Imbibed seeds were kept in darkness or in continuous incandescent light, $50 \mu \mathrm{mol} \cdot \mathrm{s}^{-1} \cdot \mathrm{m}^{-2}$ of photosynthetically active radiation (PAR) in incubators at a constant 10, 15, 20, 25, 30,35 , or 40C. Daily germination counts were made of seeds with visible radicle protrusion through the testa. Total absolute germination [percent $(\mathrm{G})$ ], days to $50 \%$ relative

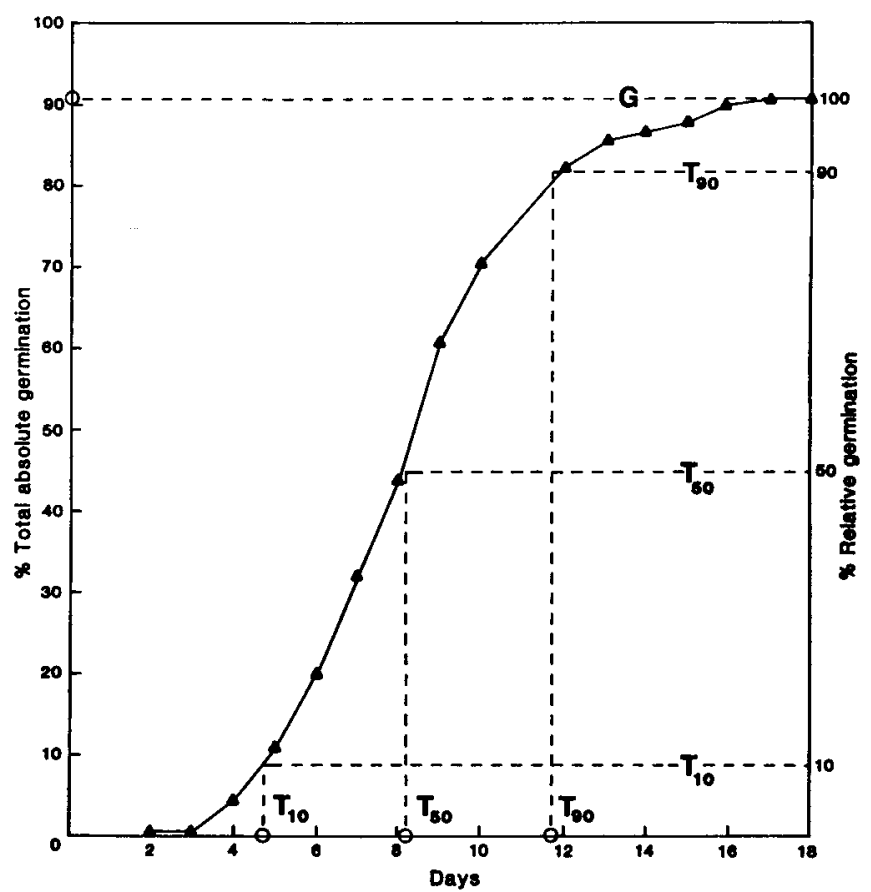

Fig. 1. Caladium cv. Candidum germination curve for freshly harvested seed at $25 \mathrm{C}$ illustrating total absolute germination $(\mathrm{G})$, days to $50 \%$ relative germination $\left(\mathrm{T}_{50}\right)$, and germination span, in days between $10 \%$ and $90 \%\left(\mathrm{~T}_{90}-\mathrm{T}_{10}\right)$. 
Table 2. Duration and number of light induction periods influence caladium seed germination.

\begin{tabular}{|c|c|c|c|c|c|}
\hline \multicolumn{3}{|c|}{ Lighting } & \multirow{2}{*}{\multicolumn{3}{|c|}{ Germination }} \\
\hline \multirow{2}{*}{$\begin{array}{l}\text { Period } \\
\text { (days) }\end{array}$} & & \multirow{2}{*}{$\begin{array}{c}\text { Duration } \\
\text { (hr) }\end{array}$} & & & \\
\hline & & & $\mathrm{G}^{2}$ & $\mathrm{~T}_{50}{ }^{\mathrm{y}}$ & $T_{90}-T_{10} x$ \\
\hline \multirow{6}{*}{\multicolumn{2}{|c|}{1}} & 0.5 & 0 & $\ldots$ & -- \\
\hline & & 1 & 0 & --- & $\cdots$ \\
\hline & & 2 & 2 & 19 & 16 \\
\hline & & 4 & 4 & 14 & 14 \\
\hline & & 8 & 5 & 11 & 11 \\
\hline & & 12 & 9 & 10 & 12 \\
\hline \multirow[t]{6}{*}{5} & & 0.5 & 0 & -- & $\cdots$ \\
\hline & & 1 & 2 & 20 & 15 \\
\hline & " & 2 & 8 & 18 & 12 \\
\hline & & 4 & 14 & 12 & $\because 11$ \\
\hline & & 8 & 26 & 10 & 9 \\
\hline & & 12 & 40 & 11 & 9 \\
\hline \multirow[t]{6}{*}{10} & $\because$ & 0.5 & 48 & 17 & 14 \\
\hline & & 1 & 61 & 16 & 12 \\
\hline & & 2 & 75 & 13 & 11 \\
\hline & & 4 & 69 & 12 & 11 \\
\hline & & 8 & 81 & 10 & 8 \\
\hline & & 12 & 90 & 8 & 6 \\
\hline \multirow[t]{6}{*}{20} & & 0.5 & 70 & 14 & 11 \\
\hline & & 1 & 78 & 12 & 8 \\
\hline & & 2 & 84 & 10 & 9 \\
\hline & & 4 & 94 & 11 & 7 \\
\hline & & 8 & 93 & 8 & 5 \\
\hline & & 12 & 96 & 8 & 5 \\
\hline \multicolumn{6}{|c|}{ Significance } \\
\hline \multicolumn{2}{|c|}{ Period (P) } & & $* *$ & $* *$ & $* *$ \\
\hline \multicolumn{2}{|c|}{ Duration (D) } & & $* *$ & $* *$ & $* *$ \\
\hline$P \times$ & & & $* *$ & $*$ & $* *$ \\
\hline
\end{tabular}

${ }^{2}$ Percent absolute final germination after 40 days. 'Days to $50 \%$ relative germination.

${ }^{x}$ Days from $10 \%$ to $90 \%$ germination.

*,** Significant $P=0.05$ or 0.01 , respectively; data are means of 400 seeds.

germination $\left(\mathrm{T}_{50}\right)$, and germination span, in number of days between $10 \%$ and $90 \%$ germination $\left(\mathrm{T}_{90}-\mathrm{T}_{10}\right)$, were calculated as recommended by Furutani et al. (1985) in this and subsequent studies (Fig. 1). The experimental design was a randomized complete block arranged as a $2 \boldsymbol{x} 7$ factorial, with data analyzed by an analysis of variance (ANOVA).

Lighting induction periods and durations. Freshly harvested seeds were cleaned, surface-dried, and germinated as described previously. Lighting durations of $0.5,1,2,4$, 8 , or $12 \mathrm{hr}$ were given for $1,5,10$, or 20 days after seed imbibition. Incubator timeclocks controlled lighting periods, and incandescent lamps provided $50 \mu \mathrm{mol} \cdot \mathrm{s}^{-1} \cdot \mathrm{m}^{-2}$ of PAR. Incubators were set at a constant 25C. Daily counts were made of seeds with emerged radicles. The experimental design was a randomized complete block as a $4 \mathrm{x}$ 6 factorial, and data were analyzed by ANOVA.

Time of seed removal from fruit. Comparisons of germination were made among seeds obtained from green fruit containing cream-colored ovaries and seeds from brown to black ovaries from fruit stored dry at $25 \mathrm{C}$ for 3,6 , or 12 weeks. Seeds from fresh and stored fruits were cleaned and germinated at $25 \mathrm{C}$ in petri dishes with continuous PAR. Daily germination counts were made of radicle emergence and data were analyzed by Duncan's multiple range test at $P=0.05$.

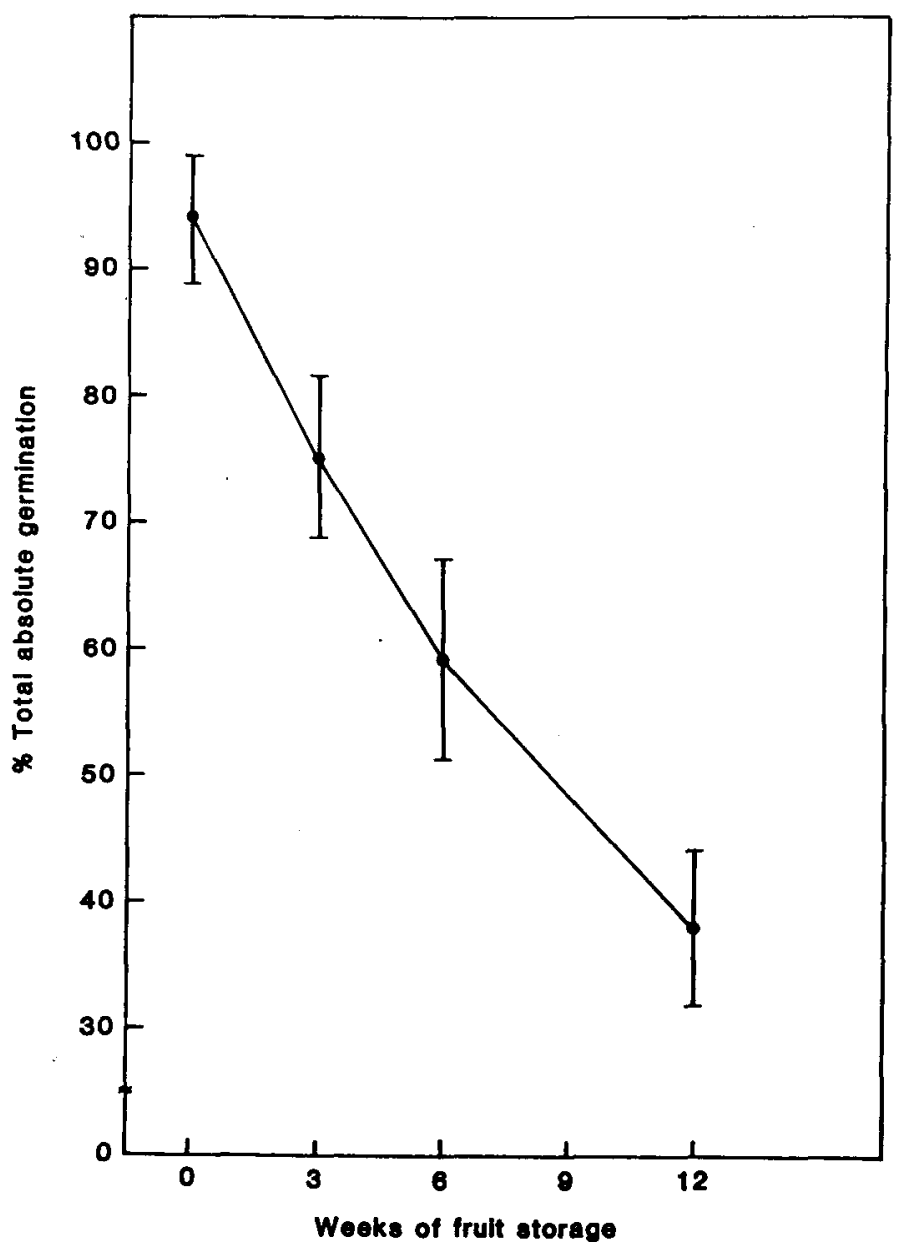

Fig. 2. Total absolute germination of seeds from freshly harvested fruit ( 0 time) and from fruit stored at $25 \mathrm{C}$ for several weeks.

Table 3. Influence of seed storage temperature, relative humidity, and duration on caladium absolute final germination percentage.

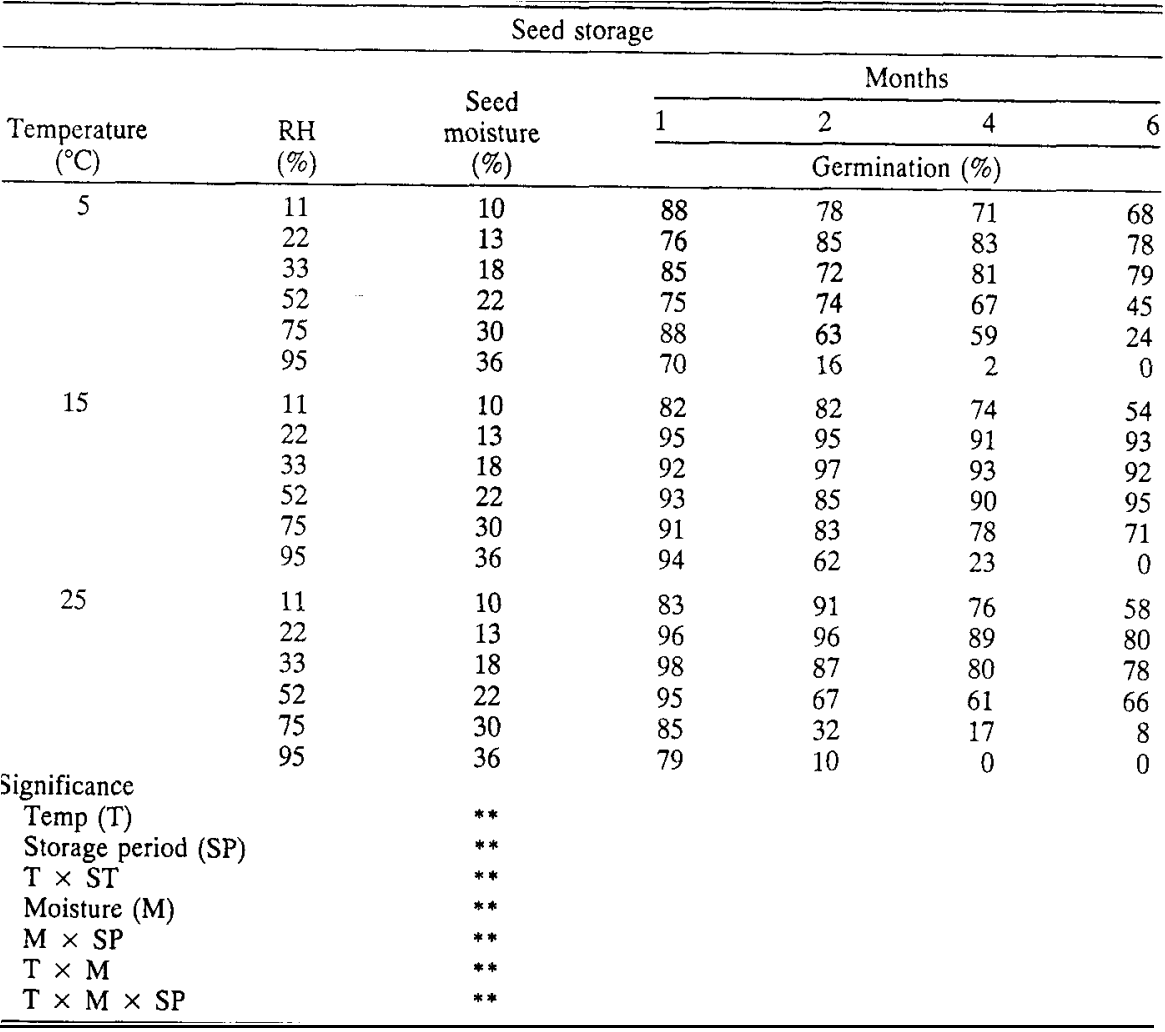




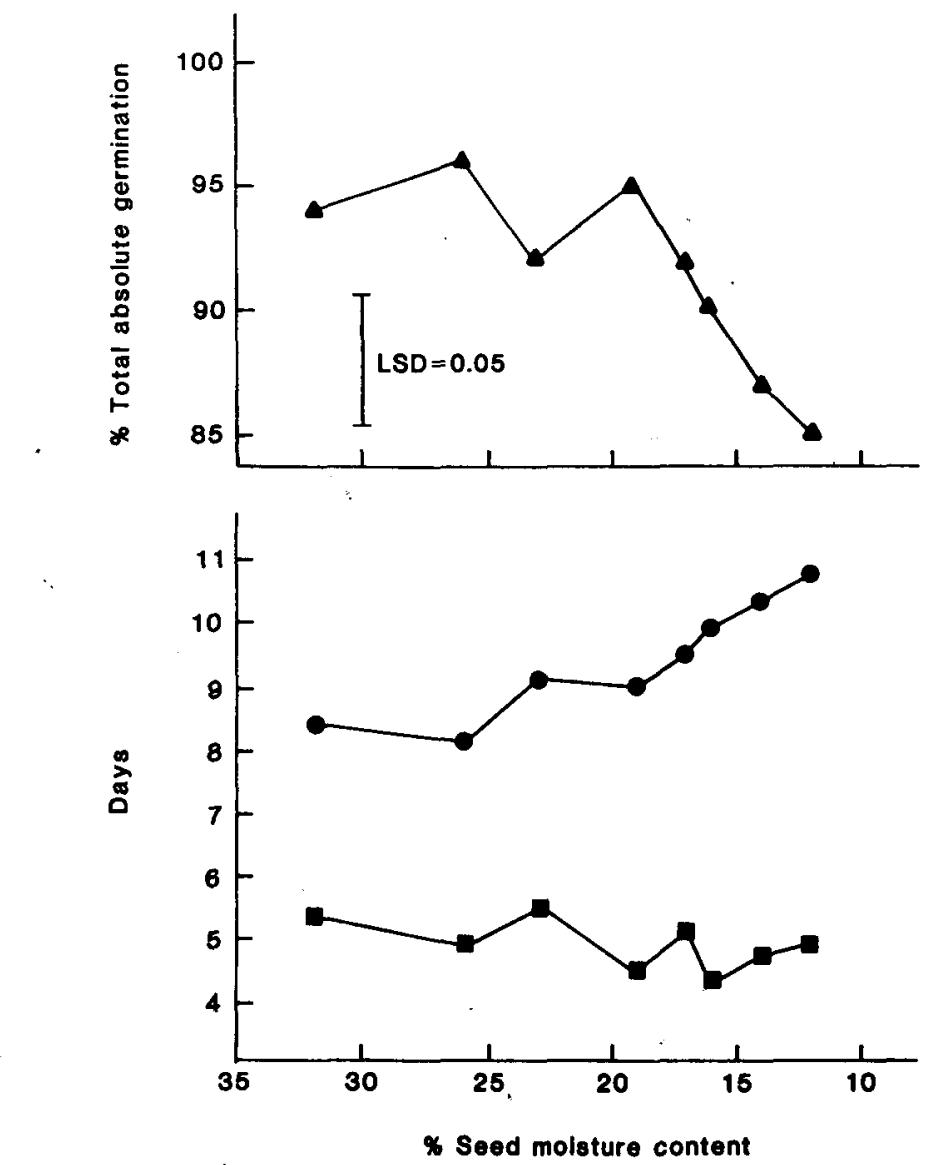

Fig. 3. Effect of secd moisture content on caladium $G(\mathbf{\Delta}), T_{50}(\bullet)$, and $T_{90}-T_{10}($
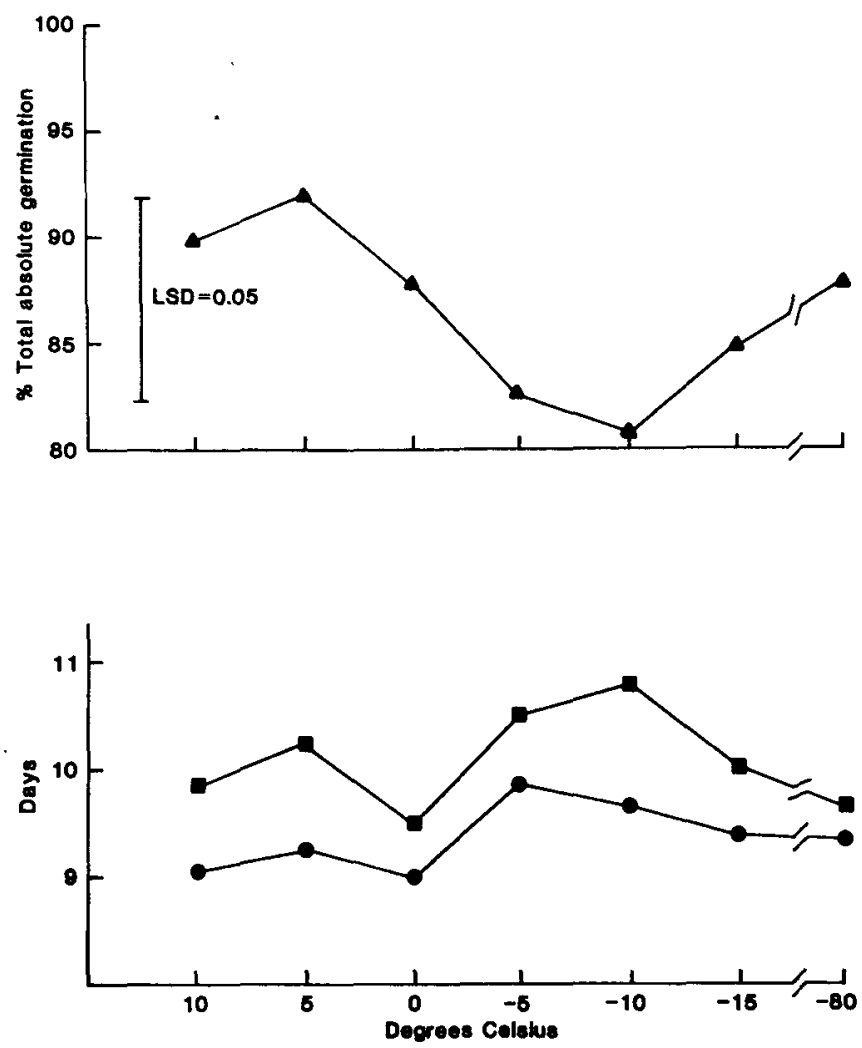

Fig. 4. Effect of seed storage temperature on caladium $G(\boldsymbol{\Lambda}), T_{50}(\bullet)$, and $T_{90}-T_{10}(\boldsymbol{\square})$.
Seed moisture content. Seeds from freshly harvested fruit were cleaned, surface-dried, placed in open $9-\mathrm{cm}$ petri dishes and dehydrated in forced-draft ovens at $40 \mathrm{C}$ for 0,1 , $2,4,8,12,24$, or $48 \mathrm{hr}$. Following dehydration, seeds were reweighed and immediately germinated; as previously described, at 25C with continuous PAR. Daily germination counts were made of seeds with radicles emerged through the testa. Germination data were analyzed using the least significant difference (LSD) at $P=0.05$. After cleaning, four 100-seed lots were weighed, dehydrated at $105 \mathrm{C}$ for $48 \mathrm{hr}$, and reweighed after cooling to determine initial moisture content.

Storage temperature. Freshly harvested seeds were cleaned, dried, and prepared as described previously. Treatments were placed in $15 \times 2.5-\mathrm{cm}$ petri dishes on wire screens supported by segments of tubing $1 \mathrm{~cm}$ above a chemical desiccant. Constant $22 \%$ RH was maintained in the sealed petri dishes by adding $50 \mathrm{ml}$ of saturated potassium acetate to the bottom of each dish (Copeland, 1976). The refrigerated incubator was maintained at $15 \mathrm{C}$ during the week of seed dehydration. Following dehydration, seeds were weighed, placed immediately in $10-\mathrm{ml}$ sealed glass vials, and immersed in polyethylene glycolwater $(\mathrm{v} / \mathrm{v})$ in controlled temperature baths (Guy and Carter, 1984) for 7 days at 10,5, $0,-5,-10,-15$, and $-80 \mathrm{C}$. Bath temperatures were lowered $3 \mathrm{C} / \mathrm{hr}$ to final temperatures, held for 7 days, then increased $4 \mathrm{C} / \mathrm{hr}$ to $10 \mathrm{C}$. Following temperature treatment, seeds were germinated with continuous light in $25 \mathrm{C}$ incubators. Daily germination counts were made of seeds with radicle protrusion through the testa and all data were analyzed using the least significant difference (LSD) at $P=0.05$.

Temperature and relative humidity interactions during seed storage. Freshly harvested seeds were cleaned, dried, and dusted with captan before storage at 11\%, 22\%, 33\%, $52 \%, 75 \%$, or $95 \% \mathrm{RH}$ and 5,15 , or $25 \mathrm{C}$ for 1,2 , 4, or 6 months. Humidity treatments were achieved as described previously, except different desiccants were used. Incubators with refrigeration and heating capacities maintained constant temperatures during seed storage. Seeds were germinated in petri dishes at $25 \mathrm{C}$ with continuous light immediately after storage. The experimental design was a randomized complete block arranged as a $3 \times 4 \times 6$ factorial, with data analyzed by ANOVA.

Exposure of imbibed seeds to light promoted germination, while continuous darkness prevented germination. No seeds germinated without light. Temperature influenced $G, T_{50}$, and $T_{90}-T_{10}$ of seeds receiving continuous light. At 25 and $30 \mathrm{C}, \mathrm{G}$ was significantly higher, while $\mathrm{T}_{50}$ and $\mathrm{T}_{90}-\mathrm{T}_{10}$ were lower than at other temperatures (Table 1). Total absolute germination progressively declined, and $\mathrm{T}_{50}$ and $\mathrm{T}_{90}-\mathrm{T}_{10}$ lengthened at temperatures above $30 \mathrm{C}$ and below $25 \mathrm{C}$. The $\mathrm{G}$ trend line for temperature was similar to linear, quadratic, and cubic, while trend lines for $T_{50}$ and $T_{90}-T_{10}$ were similar to the quadratic (Table 1). 
The number of light periods and their duration governed caladium seed germination. Significant germination differences were found among the number of light periods, the durations, and the two-way interactions. Total absolute germination was greater with 20 than 10, five, or one light induction periods, while $\mathrm{T}_{50}$ and $\mathrm{T}_{90}-\mathrm{T}_{10}$. were shorter (Table 2). Increasing daily lighting from 0.5 to $12 \mathrm{hr}$ progressively increased $\mathrm{G}$ and reduced $\mathrm{T}_{50}$ and $\mathrm{T}_{90}-\mathrm{T}_{10}$ (Table 2). Combining 20 lighting periods with 4- to 12-hr durations gave largest $\mathbf{G}$ and shortest $\mathrm{T}_{50}$ and $\mathrm{T}_{90}-\mathrm{T}_{10}$. Mayer and Poljakoff-Mayber (1979) classified seeds requiring light for germination into groups requiring brief periods and continuous light. Caladium seeds require light daily for $4 \mathrm{hr}$ or longer for maximum $\mathrm{G}$.

Caladium $\mathrm{G}$ declined if seeds remained in fruits after release from the spadix. Progressively lower $\mathrm{G}$ was found as the duration in the fruit after harvest was increased from $\mathrm{O}$ to 12 weeks (Fig. 2). Whether reduced $G$ results from seeds in the fruit entering a secondary dormancy or is caused by lost viability is unknown. The rapid loss in seed viability reported by Hartman et al. (1972) and by commercial producers could be related to delayed cleaning of seeds after harvesting caladium fruit.

Caladium seeds were only moderately tolerant of desiccation. Total absolute germination was similar from $32 \%$ to $16 \%$ moisture contents, but $14 \%$ and $12 \%$ moisture levels caused statistically significant but small reductions (Fig. 3). Reducing seed moisture contents from $32 \%$ to $12 \%$ left $\mathrm{T}_{50}$ and $\mathrm{T}_{90}-\mathrm{T}_{10}$ unchanged (Fig. 3). Caladium seeds in this study were more tolerant of low moisture contents than reported by Hartman et al. (1972), and seed desiccation did not contribute to-irregular germination, as found by Job et al. (1982).

Seeds were very cold-tolerant and G generally was similar among all temperature treatments (Fig. 4). Fifty percent relative germination and $\mathrm{T}_{90}-\mathrm{T}_{10}$ were unchanged by 7 days of storage of seeds with $18 \%$ moisture content at temperatures from 10 to $-80 \mathrm{C}$ (Fig. 4). Seeds were more cold-tolerant than caladium tubers or plants. Harbaugh (1983) reported $13 \mathrm{C}$ for $72 \mathrm{hr}$ to cause $40 \%$ of caladium leaves to abscise, with $100 \%$ foliage loss below 10C. Marousky (1974) found tubers exposed to 5 to $15 \mathrm{C}$ for 10 days were inhibited from sprouting during a subsequent forcing period.

Seed storage for 6 months without reduction in $\mathrm{G}$ was possible at $15 \mathrm{C}$ and $22 \%, 33 \%$, or $52 \% \mathrm{RH}$, but 5 or $25 \mathrm{C}$ storage at these relative humidities significantly reduced $\mathrm{G}$ (Table 3). Storage at $75 \%$ or $95 \%$ RH for periods exceeding 1 month caused losses in $\mathrm{G}$, with smaller reductions at $15 \mathrm{C}$ than 5 or $25 \mathrm{C}$. Total absolute germination progressively declined at all temperatures during 6 months of seed storage at $11 \% \mathrm{RH}$ (Table 3 ). Seeds dehydrated at $105 \mathrm{C}$ after 6 months of storage at $11 \%$ RH contained $14 \%$ moisture, which the dehydration study showed reduced $\mathrm{G}$ (Fig. 3).

These studies provide information to ex- plain caladium seed germination failure, irregular germination, and rapid loss of viability after seed drying and storage. Recommendations for seed germination, handling, and storage are necessary for the introduction of inbred lines as cultivars. Genetically uniform caladiums from. direct seeding of cultivars from inbred lines would have potential as bedding plants. Harbaugh (1983) found bedding plant "plugs" with three to four leaves reached marketable size in 10-cm (0.8-liter) pots in 6 weeks after transplanting. Plants were uniform in size, disease-free, and had many small highly colored leaves.

\section{Literature Cited}

Copeland, L.O. 1976. Principles of seed science and technology. Burgess, Minneapolis.

Furutani, S. C., B.H. Zandstra, and H.C. Rice. 1985. Low temperature germination of celery seeds for fluid drilling. J. Amer. Soc. Hort. Sci. 110:149-153

Guy, C.L. and J.V. Carter. 1984. Characterization of partially purified glutathione reductase from cold hardened and nonhardened spinach leaf tissue. Cryobiology 21:454-464.

Harbaugh, B.K. 1983. Caladiums as bedding plants. Fla. Orn. Growers Assn. Nwsl. 6(2)34.

Hartman, R. D., F.W. Zettler, J.F. Knauss, and E.M. Hawkins. 1972. Seed propagation of caladium and dieffenbachia. Proc. Fla. State Hort. Soc. 85:404-409.

Job, J. S., K.V. Bai, and N. Hrishi. 1982. Major factors limiting seed set in aroids. 5th Intl. Symp. Trop. Root and Tuber Crops. Kerala, India. p. 697-702.

Lecoufle, M. 1982. Caladium propagation. U.K. Garden 107(10):404-407.

Marousky, F.J. 1974. Influence of curing and low temperature during storage on subsequent sprouting of caladium tubers. Proc. Fla. State Hort. Soc. 87:426-428.

Mayer, A.M. and A. Poljakoff-Mayber. 1975. The germination of seeds. 2nd ed. Pergamon, New York.

Post, K. 1949. Florist crop production and marketing. Orange-Judd, New York.

Wilson, M.R. and T.A. Nell. 1984. Caladiums. Greenhouse Manager 3(4):68-73.

\title{
Growth and Transplantability of Magnolia grandiflora Following Root Pruning at Several Growth Stages
}

\author{
Edward F. Gilman and Michael E. Kane \\ Ornamental Horticulture Department, IFAS, University of Florida, \\ Gainesville, FL 32611
}

Additional index words. southern magnolia, shoot : root ratio, post-transplant growth

Abstract. Roots of field-grown southern magnolia (Magnolia grandiflora L.) were pruned once during dormancy, following the first shoot growth flush or after the second growth flush or twice at the following times: during dormancy and following first growth flush, during dormancy and following second growth flush, following first and second growth flush before transplanting in the winter. By the end of the growing season, root pruning at all stages of growth reduced leaf number, tree height, trunk caliper, and total tree leaf area and weight compared with unpruned controls. Total root weight was less for trees pruned during dormancy or following the first growth flush. Root pruning increased the proportion of fine roots $(0-$ to $5-\mathrm{mm}$-diameter class) to coarse roots $(>5$ to 10 -mm-diameter class). Shoot : root dry weight ratios at transplanting were not affected by root pruning. Root-pruned trees grew at a faster rate following transplanting than unpruned trees. Despite these initial differences. trees in all treatments were the same size 1 year after transplanting.

Root-pruning of trees in fruit, forest, and landscape tree nurseries is an old and varied practice (Hawley and Smith, 1954). It has been used as a horticultural tool to produce a sturdier tree; force development of a more

Received for publication 10 Apr. 1989. Florida Agriculture Experiment Station Journal Series no. 9859. We wish to acknowledge the support of Big Trees Nursery, Newberry, Fla. for their support in conducting this study. The cost of publishing this paper was defrayed in part by the payment of page charges. Under postal regulations, this paper therefore must be hereby marked advertisement solely to indicate this fact. compact, fibrous root system; retard top growth; and increase transplant "survival and post-transplant growth (Mullin, 1966). The timing, frequency, severity, and location of root pruning are governed more by practical experience and tradition than by scientific studies. Only recently have the effects of root pruning on pre- and post-transplant tree growth been studied.

A recognized plant response to root pruning is reduction of shoot growth, an effect found in apple (Malus domestics Borkh.) (Maggs, 1965), orange [Citrus sinensis (L.) Osbeck] (Alexander and Maggs, 1971), and white spruce (Picea glauca Moench) (Mul- 